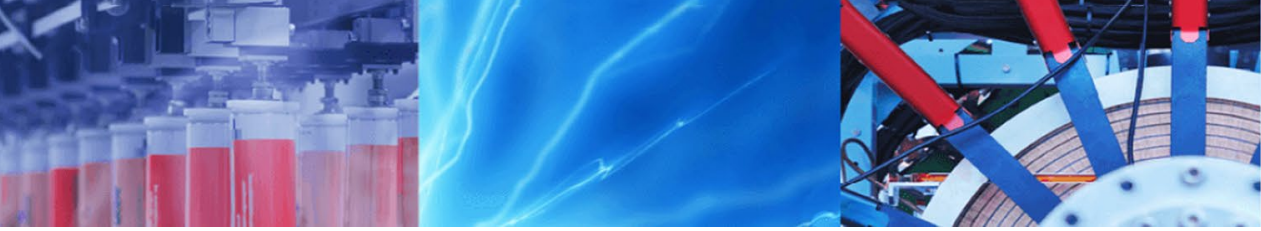

Research Article

\title{
Oxidase-like activity of magnetically separable nano ceria for catechol detection
}

\author{
Suraj V. Yadav ${ }^{1} \cdot$ Virendra K. Rathod $^{1}$
}

() Springer Nature Switzerland AG 2019

\begin{abstract}
The present work demonstrates the use of novel properties of ceria magnetic nanoparticles $\left(\mathrm{CeO}_{2}-\mathrm{Fe}_{3} \mathrm{O}_{4} \mathrm{NPs}\right)$ as oxidase mimetics to detect catechol. The $\mathrm{CeO}_{2}-\mathrm{Fe}_{3} \mathrm{O}_{4} \mathrm{NPs}$ was prepared by simple co-precipitation method. The prepared nanoparticles were confirmed by different techniques such as FTIR, XRD, SEM-EDS, and XPS. $\mathrm{CeO}_{2}-\mathrm{Fe}_{3} \mathrm{O}_{4} \mathrm{NPs}$ exhibits similar activity as tyrosinase enzyme to catalyse the oxidation of colorless catechol to colored quinone complex, which provides colorimetric detection of catechol. Characterization techniques show that the oxidase activity of the $\mathrm{CeO}_{2}-\mathrm{Fe}_{3} \mathrm{O}_{4}$ NPs initiates due to $\mathrm{Ce}^{4+} / \mathrm{Ce}^{3+}$ and quinone complex formation by catechol ligand. In addition, $\mathrm{CeO}_{2}-\mathrm{Fe}_{3} \mathrm{O}_{4} \mathrm{NPs}$ can be easily separated from the reaction solution by using a magnet and reused for the next cycle.
\end{abstract}

Keywords Ceria magnetic nanoparticles $\cdot$ Enzyme mimic $\cdot$ Catechol detection $\cdot$ Quinone complex $\cdot$ Nanozyme

\section{Introduction}

Natural enzymes are used in the analysis of biological and chemical substances, food processing, and in biofuel production. It is also widely used in the synthesis of pharmaceuticals and fine chemicals due to their high substrate specificities and high catalytic efficiency under mild conditions $[1,2]$. However, they also have inherent restrictions such as expensive techniques for preparation and purification, unstability affected by denaturation, and inadequacy for large-scale applications [2, 3]. Therefore, with developments in artificial enzyme, the replacement of enzyme by other material is possible, as they not only have benefits with respect to cost, easy storage, and stability but also provide high substrate specificities [4-6].

Ceria metal nanoparticles (NPs) have received significant attention in latest years [7-10] because of their special properties due to large surface area $[10,11]$, quantum confinement, and super paramagnetism, which are very dissimilar from the properties demonstrated by the identical materials in bulk form. $\mathrm{Fe}_{3} \mathrm{O}_{4}$ magnetic nanoparticles demonstrate an enzyme mimic activity, analogous to naturally peroxidases [3]. A variety of inorganic nanomaterials have been established as enzyme mimics [12-17], accompanied by transition and inner-transition metal oxides $\left(\mathrm{CeO}_{2}, \mathrm{CuO}, \mathrm{FeS}, \mathrm{CuS}\right.$, and FeSe), carbon-based nanomaterials and noble metals ( $\mathrm{Au}$ and $\mathrm{Pt})[1,2,18]$. One area of intense scientific interest is nanoparticles that show enzyme-like activity [3,19-21]. Even though natural enzymes show good catalytic activity and selectivity, they can be destabilized by environmental conditions $[18,22]$. Purification and immobilization of natural enzymes can be costly and time-consuming $[1,18,22]$, requiring complex and expensive technology such as chromatography and electrophoresis. In contrast, nanomaterials are stable, easily synthesized, inexpensive, have high catalytic efficiency, and selectivity.

Till date, a wide range of nanoparticles has been recognized as enzyme mimetics, containing metal oxides and carbon-based nanostructure. These nanomaterials seem to encompass an infinite number of potential structures; though, it is possible that they possess $\square$ Virendra K. Rathod, vk.rathod@ictmumbai.edu.in| ${ }^{1}$ Department of Chemical Engineering, Institute of Chemical Technology, Matunga
(E), Mumbai 400019, India.

SN Applied Sciences (2019) 1:1071 | https://doi.org/10.1007/s42452-019-0971-9 
several unifying and classifying principles. Usually, the enzyme-like activities of nanomaterials can be divided into four categories: (1) peroxidase-like, (2) oxidase-like, (3) superoxide dismutases like (SOD) and (4) catalase like enzyme activities $[1,23,26]$. Other nanoparticles (NPs) such as $\mathrm{CeO}_{2}$ and $\mathrm{Co}_{3} \mathrm{O}_{4} \mathrm{NPs}$ are competitive candidates to substitute SOD. Sometimes single nanomaterial can show more than one enzyme-like property and those enzyme-like activities may change depending on external conditions. For example, nanomaterials containing precious metals, such as Au and Ag NPs, display peroxidase-like activities under acidic conditions, but catalaselike activities under alkaline conditions [4, 24]. Although significant efforts have been expended to develop enzyme-like nanomaterials over the past decade, most nanomaterials research has focused on achieving catalase-like and peroxidase-like activity [2]. Nanomaterials having oxidase-like activities has received less attention [1]. Polyphenol oxidases are of interest because of unique properties and their effects on the polyphenols extensively found in natural products, which have long been thought to be beneficial to human health. Biochemical investigations in 1895 considered the oxidation of phenolic compounds to quinones and their subsequent polymerization to be the major path for melanin formation. In humans, areas of increased accumulation of melanin in the skin or the redistribution of epidermal melanin can effect dark or light patches which may be considered aesthetically disagreeable. In plant materials, the polymerization of polyphenols causes the enzymatic browning of fruits and vegetables, resulting in altered nutritional and organoleptic properties, diminished storage life and product value [25]. Nevertheless, oxidations of polyphenols can be helpful and even considered essential to the quality of a product. In the processing of black tea, coffee, and cocoa, oxidation improves the quality of the beverages, making products more flavorful and providing distinctive organoleptic properties. As the oxidation of polyphenols has diverse and significant biological roles, the possibility that certain nanomaterials could display oxidase-like properties must be investigated and understood.

In this study, we report that $\mathrm{CeO}_{2}-\mathrm{Fe}_{3} \mathrm{O}_{4} \mathrm{NPs}$ were synthesized and used for the first time by the colorimetric method for catechol detection by oxidation of $o$-diphenols to o-quinones. Also, the oxidase activity of $\mathrm{CeO}_{2}-\mathrm{Fe}_{3} \mathrm{O}_{4} \mathrm{NPs}$ was checked and compared with the tyrosinase enzyme. We have investigated these oxidation processes using UV-vis spectrophotometry. Our findings provide important insights, which can provide information on structural properties and future applications of $\mathrm{CeO}_{2}-\mathrm{Fe}_{3} \mathrm{O}_{4} \mathrm{NPs}$. This will help in the detection of other polyphenolic compounds.

\section{Materials and methods}

\subsection{Materials}

Ammonium ceric nitrate, ferrous chloride $\left(\mathrm{FeCl}_{2} \cdot 4 \mathrm{H}_{2} \mathrm{O}\right)$, ferric chloride $\left(\mathrm{FeCl}_{3}\right)$, ammonia solution, Ascorbic acid and catechol were purchased from HiMedia Laboratories Pvt. Ltd. Mumbai, India. Tyrosinase with $1000 \mathrm{U} / \mathrm{mg}$ activity was procured from Sigma Aldrich Pvt. Ltd, India. Deionized (DI) water with conductivity of 0.055 microsiemens was used for all the experiments.

\subsection{Methods}

\subsection{1 $\mathrm{Fe}_{3} \mathrm{O}_{4}$ Magnetic nanoparticle synthesis}

Precipitation method was used for the synthesis of magnetic nanoparticles [26]. The ferrous ions and ferric ions were dissolved in $40 \mathrm{~mL}$ sonicated deionized water at a molar ratio of 1:2. Further the reaction was carried out in a $50 \mathrm{~mL}$ glass reactor with continuous stirring (100 rpm) at $50{ }^{\circ} \mathrm{C}$. After $30 \mathrm{~min}$ of mixing, $\mathrm{pH} 12$ was adjusted by adding $\mathrm{NH}_{3}$ solution and further stirred for $30 \mathrm{~min}$. Thereafter, resulting MNPs were centrifuged, washed and dried at $60^{\circ} \mathrm{C}$ for $2 \mathrm{~h}$.

\subsubsection{Synthesis of $\mathrm{CeO}_{2}-\mathrm{Fe}_{3} \mathrm{O}_{4}$ nanoparticles}

$\mathrm{CeO}_{2}-\mathrm{Fe}_{3} \mathrm{O}_{4}$ NPs was prepared from ammonium ceric nitrate hexahydrate by precipitation method [27-29]. $0.2 \mathrm{~g}$ ammonium ceric nitrate hexahydrate was dissolved in $30 \mathrm{~mL}$ DI water, which was taken in a $50 \mathrm{~mL}$ glass reactor at $50{ }^{\circ} \mathrm{C}$ temperature with $100 \mathrm{rpm}$ stirring and $\mathrm{pH} 12$ was maintained by adding ammonia solution to precipitate ceria nanoparticles. Further, $1 \mathrm{~g} \mathrm{Fe}_{3} \mathrm{O}_{4} \mathrm{NPs}$ was added and the reaction was agitated for $1 \mathrm{~h}$. The reaction mixture was centrifuged and washed with DI water. The collected precipitate was dried at $60{ }^{\circ} \mathrm{C}$ and $\mathrm{Ce}$ doped $\mathrm{Fe}_{3} \mathrm{O}_{4} \mathrm{NPs}$ magnetically separable catalyst was synthesized.

\subsubsection{Oxidase like activity}

To study the oxidase mimicking activity of ceria magnetic nanoparticles, different concentrations of catechol (1-7 mM), $\mathrm{CeO}_{2}-\mathrm{Fe}_{3} \mathrm{O}_{4} \mathrm{NPs}(1-9 \mathrm{mg})$ and phosphate buffer solution $(0.05-1 \mathrm{M})$ with $\mathrm{pH} 7.8$ was examined at various times intervals (5-20 $\mathrm{min}$ ) at room temperature. On completion of the reaction, $\mathrm{CeO}_{2}-\mathrm{Fe}_{3} \mathrm{O}_{4} \mathrm{NPs}$ was separated by an external magnet and checked for quinone complex formation by measuring absorbance using spectrophotometer [1]. The effect of $\mathrm{CeO}_{2}-\mathrm{Fe}_{3} \mathrm{O}_{4} \mathrm{NPs}$ concentration 
was inspected in the range of 1-9 $\mathrm{mg}$, using $5 \mathrm{mM}$ catechol. Also, the optimization of time and ionic strength was studied by using $5 \mathrm{mg} \mathrm{CeO}-\mathrm{Fe}_{3} \mathrm{O}_{4} \mathrm{NPs}$ with $5 \mathrm{mM}$ catechol concentration. The effect of time was studied in buffer solutions for 5-20 min at room temperature and consequence of ionic strength was observed in buffer concentration changing from 0.05 to $1 \mathrm{M}(\mathrm{pH} 7.8)$. The absorbance was measured in the visible range. The absorbance of quinone complex due to tyrosinase enzyme was compared with $\mathrm{CeO}_{2}-\mathrm{Fe}_{3} \mathrm{O}_{4} \mathrm{NPs}$ generated quinone complex.

The interference study for catechol detection has been carried out by adding $5 \mathrm{mM}$ ascorbic acid in the solution containing catechol $(5 \mathrm{mM})$ and $\mathrm{CeO}_{2}-\mathrm{Fe}_{3} \mathrm{O}_{4} \mathrm{NPs}(5 \mathrm{mg})$, the absorbance of the colored solution was measured and compared with the ascorbic acid solution.

\subsubsection{Characterization of prepared $\mathrm{CeO}_{2}-\mathrm{Fe}_{3} \mathrm{O}_{4}$ nanoparticles}

The prepared ceria magnetic nanoparticles $\left(\mathrm{CeO}_{2}-\mathrm{Fe}_{3} \mathrm{O}_{4}\right.$ NPs) were characterized, using Fourier transform infrared spectra (FTIR) recorded over $400-4000 \mathrm{~cm}^{-1}$ on a Shimadzu IR affinity-1S spectrometer using DRS 8000 accessory. The crystal structure of the ceria magnetic nanoparticles was studied using X-ray diffraction (XRD) $\left(2 \theta=5^{\circ}-80^{\circ}\right.$, Bruker AXS powder diffractometer, D8-Advance). The XRD analysis was done by scanning the sample within a range of 5-80 $2 \theta$ (degree) for $2 \mathrm{~h}$, using monochromatized $\mathrm{Cu} \mathrm{Ka}$ radiation (1.54 $\AA$ ). The uniform distribution of ceria magnetic nanoparticles was determined by using elemental mapping analysis. This was also further supported by scanning electron microscopy with energy dispersive $\mathrm{X}$-ray spectroscopy (SEM-EDX), transmission electron microscopy (TEM), X-ray photoelectron spectroscopy (XPS) Analysis.

\section{Results and discussion}

\subsection{Characterization of magnetically separable ceria $\left(\mathrm{CeO}_{2}-\mathrm{Fe}_{3} \mathrm{O}_{4}\right) \mathrm{NPs}$}

The FTIR spectra of $\mathrm{CeO}_{2}-\mathrm{Fe}_{3} \mathrm{O}_{4}$ magnetic nanoparticles is shown in Fig. 1. The spectrum of the $\mathrm{CeO}_{2}-\mathrm{Fe}_{3} \mathrm{O}_{4}$ NPs shows a peak in the range of $500-600 \mathrm{~cm}^{-1}$ which is metal-oxygen stretching vibration in the tetrahedral site [27].

XRD pattern of the synthesized $\mathrm{CeO}_{2}-\mathrm{Fe}_{3} \mathrm{O}_{4} \mathrm{NPs}$ is shown in Fig. 2. According to JCPDS card number 01-0750449 database, the peak at $2 \theta=35.64^{\circ}$ recognized to $(1$ $10)$ plane of $\mathrm{Fe}_{3} \mathrm{O}_{4}$. They have rhombohedral structure and sharp reflections indexed to be face centered cubic phases. The precursor impurities are not observed in XRD pattern. The crystalline size of the magnetic nanoparticles was determined from the Debye-Scherrer formula $D_{h k l} 1 / 4$ $0.89 \lambda / \beta \cos \theta$, where $D$ is the crystallite size in $n m, \beta$ is the full width at half maximum intensity in radian, $\theta$ is the Bragg diffraction angle and $\lambda$ is the $X$-ray wavelength in $\mathrm{nm}$ [28]. The crystallite size of the $\mathrm{CeO}_{2}-\mathrm{Fe}_{3} \mathrm{O}_{4} \mathrm{NPs}$ by using the Debye-Scherrer equation was found to be $20 \mathrm{~nm}$. The ceria peak is not seen in XRD spectrum due to low percentage doping of ceria on the surface of $\mathrm{Fe}_{3} \mathrm{O}_{4}$ nanoparticles.

To confirm ceria present on $\mathrm{Fe}_{3} \mathrm{O}_{4} \mathrm{NPs}$, the SEM-EDX analysis was done. The SEM-EDX shows that $6 \%$ ceria is present on the surface of $\mathrm{Fe}_{3} \mathrm{O}_{4} \mathrm{NPs}$. Elemental mapping analysis shows that $\mathrm{Ce}$, $\mathrm{Fe}$ and Oxygen elements co-exist in the nanoparticles and ceria is present on the surface of $\mathrm{Fe}_{3} \mathrm{O}_{4} \mathrm{NPs}$. Elemental mapping confirms that $\mathrm{Ce}, \mathrm{Fe}$, and $\mathrm{O}$ elements are uniformly distributed in $\mathrm{CeO}_{2}-\mathrm{Fe}_{3} \mathrm{O}_{4} \mathrm{NPs}$, which is shown in Fig. 3a-c.

The chemical status of $\mathrm{CeO}_{2}-\mathrm{Fe}_{3} \mathrm{O}_{4} \mathrm{NPs}$ was analyzed by $\mathrm{X}$-ray photoelectron spectroscopy (XPS). The binding
Fig. 1 FTIR spectra of $\mathrm{CeO}_{2}-$ $\mathrm{Fe}_{3} \mathrm{O}_{4} \mathrm{NPs}$

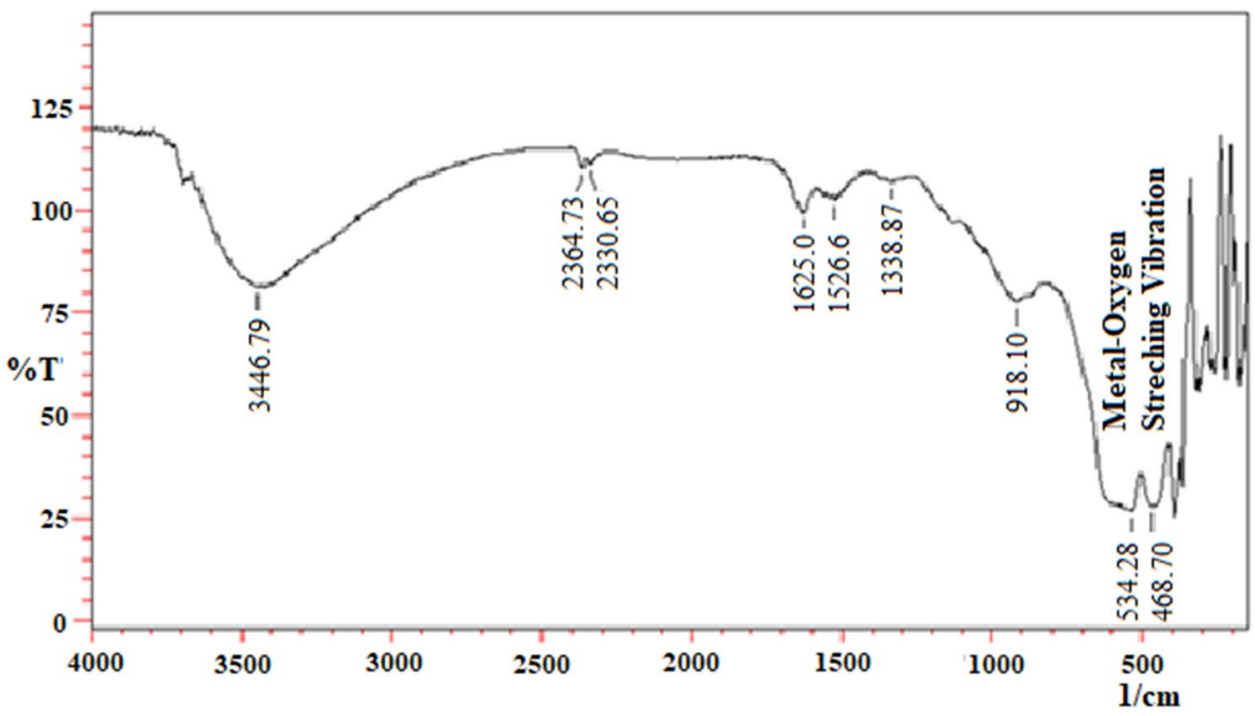

SN Applied Sciences a SPRINGER NatURE journa 
Fig. 2 XRD pattern of the synthesized $\mathrm{CeO}_{2}-\mathrm{Fe}_{3} \mathrm{O}_{4} \mathrm{NPs}$
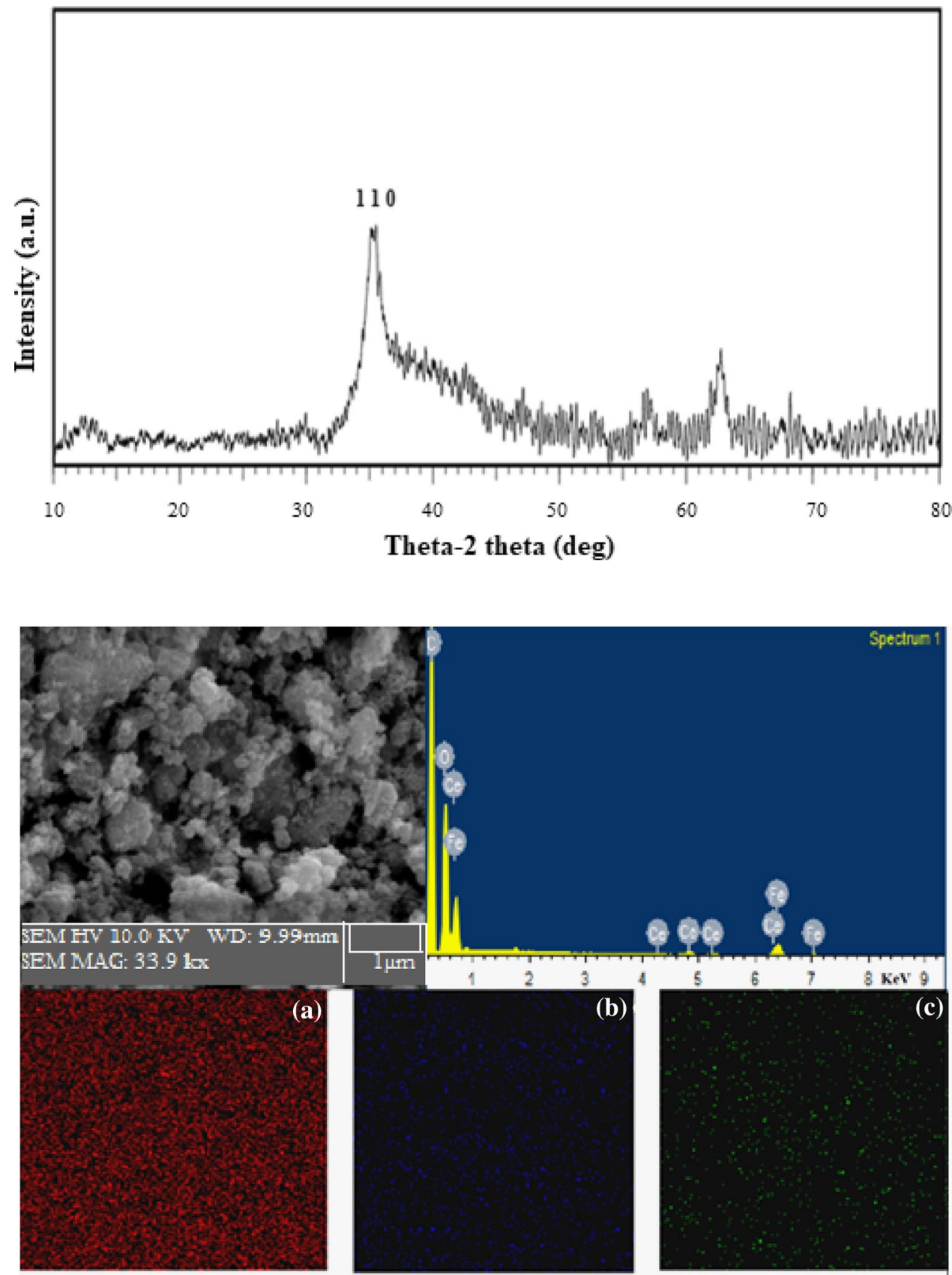

O Ka1

Fe Ka1

Ce La1
Fig. 3 SEM-EDX and elemental mapping showing uniform distribution of $\mathrm{CeO}_{2}-\mathrm{Fe}_{3} \mathrm{O}_{4} \mathrm{NPs}$. a Oxygen distribution, b Fe distribution, c Ce distribution energy can be used to determine the oxidation state. Therefore we can say that with an increase in a valence state of the element, its binding energy also increases. XPS survey spectra in Fig. 4a shows that the nanoparticles contained $\mathrm{Ce}$, Fe, $\mathrm{O}$ and $\mathrm{C}[18,29]$. The Fe $2 p$ XPS spectrum in Fig. $4 \mathrm{~b}$ shows that the peaks at binding energies (BE) of 710 and $723 \mathrm{eV}$ were of $\mathrm{Fe}^{2+}$, while the peak at binding energies (BE) of 713 and $726 \mathrm{eV}$ was characteristic of $\mathrm{Fe}^{3+}$. The combination of $\mathrm{Fe}^{2+}$ and $\mathrm{Fe}^{3+}$ is confirmed due to satellite signal at $718 \mathrm{eV}$. $\mathrm{Fe}^{3+}$ and $\mathrm{Fe}^{2+}$ existing in the sample confirm the formation of $\mathrm{Fe}_{3} \mathrm{O}_{4}$, whereas satellite signals at $715 \mathrm{eV}$ and $719 \mathrm{eV}$ are of $\mathrm{Fe}^{2+}$ and $\mathrm{Fe}^{3+}$ [29-31].

The lattice oxygen ( $\mathrm{O} 1 \mathrm{~s}$ ) core level spectrum peak at $529 \mathrm{eV}$ of $\mathrm{Fe}_{3} \mathrm{O}_{4}$ NPs is depicted in Fig. 4a [29, 32-35]. The XPS peak of Ce $3 d$ doublet, its satellite peaks (S1 and S2), main $\mathrm{Ce} 3 d_{5 / 2}$ and $\mathrm{Ce} 3 d_{3 / 2}$ lines are shown in the Fig. $4 \mathrm{C}$. The Ce two phases are identified by different positions and intensities of the shake up satellite peaks. The shape of measured $\mathrm{Ce} 3 d$ line shows two satellite peaks. Its first satellite S1 is at $890 \mathrm{eV}$ and the second satellite S2 is more intense at $897 \mathrm{eV}$. The satellite S2 partially overlaps with 

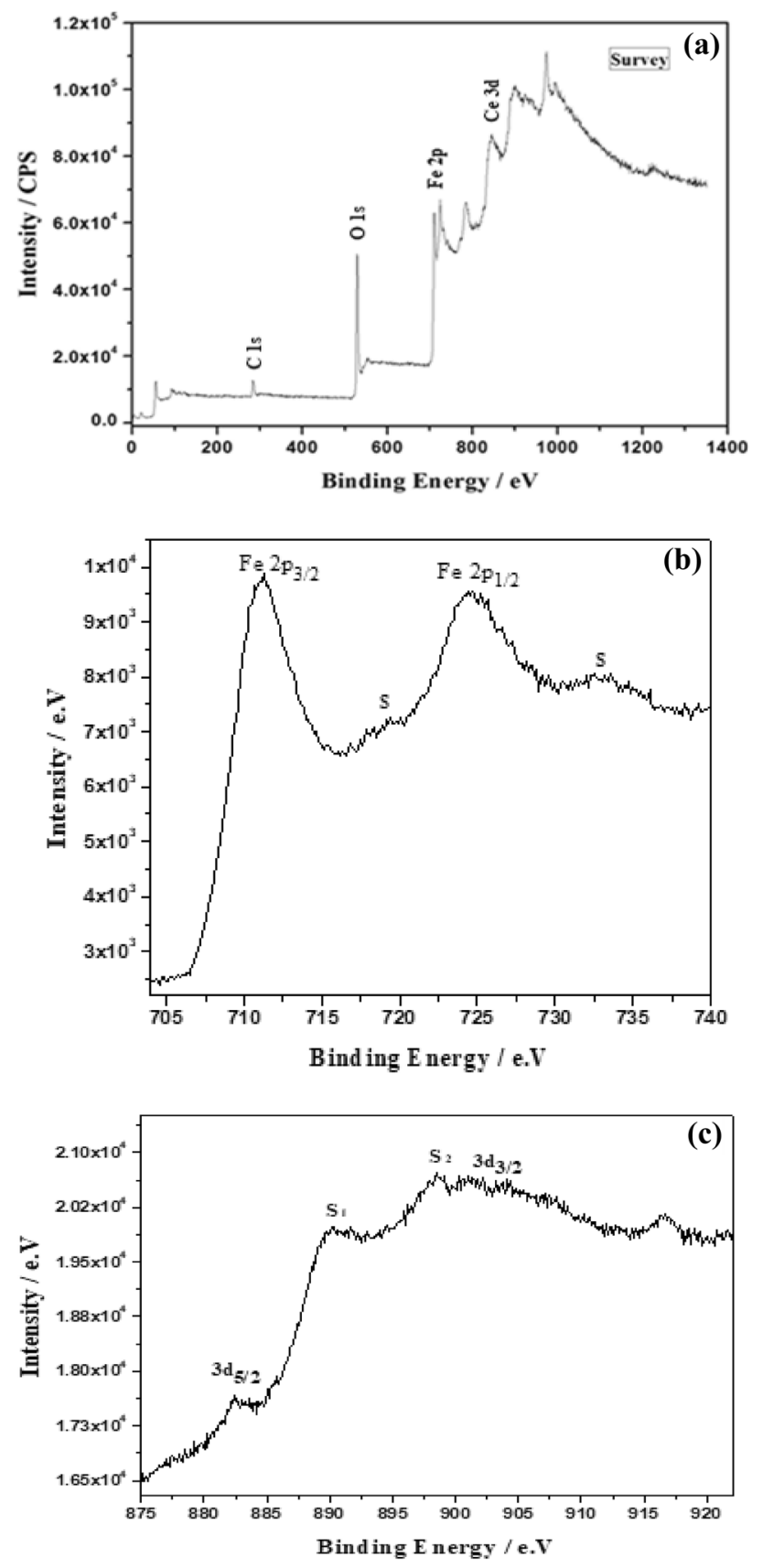

Fig. 4 a XPS survey spectra for $\mathrm{CeO}_{2}-\mathrm{Fe}_{3} \mathrm{O}_{4}$ NPs, b XPS spectra for $\mathrm{Fe}$ in $\mathrm{CeO}_{2}-\mathrm{Fe}_{3} \mathrm{O}_{4} \mathrm{NPs}$, c XPS spectra for $\mathrm{Ce}$ in $\mathrm{CeO}_{2}-\mathrm{Fe}_{3} \mathrm{O}_{4} \mathrm{NPs}$

$3 d_{3 / 2}$ line. The peak in range $915-920 \mathrm{eV}$ is due to the oxygen vacancy in metal oxides that shows $\mathrm{Ce}^{3+}$ on the surface. However, the main Ce $3 d_{5 / 2}$ line is seen at $882 \mathrm{eV}$, while $\mathrm{Ce} 3 d_{3 / 2}$ is observed at $901 \mathrm{eV}$. The positions of peaks are in good agreement with the literature, which further supports the suggested phase identification [29, 32].

The Ce $3 d$ binding energy is higher by 0.6 than reported literature, and $\mathrm{Fe} 2 p$ binding energy is $0.5 \mathrm{eV}$ less than the reported literature of $\mathrm{Fe}_{3} \mathrm{O}_{4}$ binding energy. These

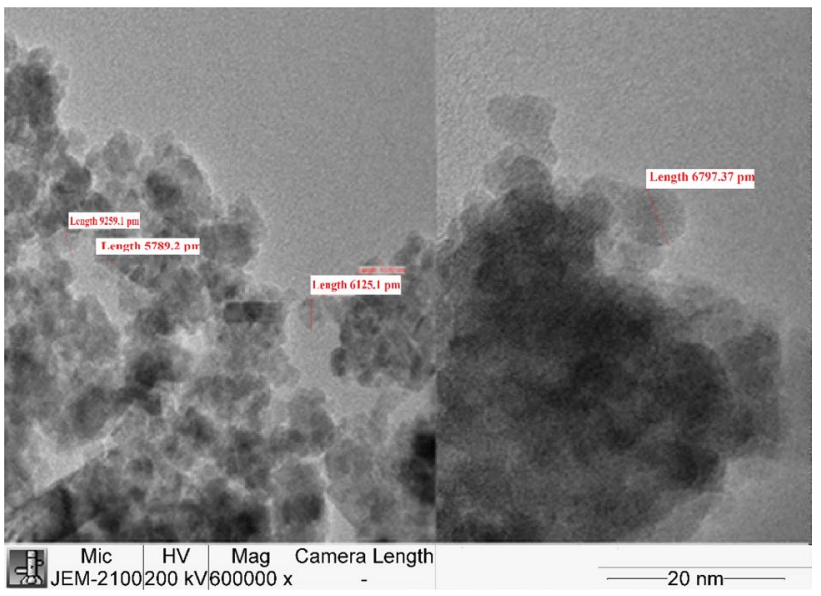

Fig. 5 TEM analysis of $\mathrm{CeO}_{2}-\mathrm{Fe}_{3} \mathrm{O}_{4} \mathrm{NPs}$

difference in binding energy is due to formation of $\mathrm{CeO}_{2}$ composition on the surface of $\mathrm{Fe}_{3} \mathrm{O}_{4}[33,34]$.

XRD and XPS both are surface analysis techniques as well as XPS is more sensitive than XRD. XPS detects signals within upper than $5 \mathrm{~nm}$ thickness and XRD detects signals in micro-order thickness on surface $[35,36]$. To confirm the particle size of MNPs TEM analysis was carried out that shown in Fig. 5. The Particle size is found to be $9 \mathrm{~nm}$ and morphology of nanoparticles are found to be spherical in shape. XRD results show the crystalite size of $20 \mathrm{~nm}$ calculated by Scherrer formulae, whereas TEM analysis shows particle size of $9 \mathrm{~nm}$.

\subsection{Oxidase like activity: proof for the concept for $\mathrm{CeO}_{2}-\mathrm{Fe}_{3} \mathrm{O}_{4}$ based detection}

The oxidase like activity of $\mathrm{CeO}_{2}-\mathrm{Fe}_{3} \mathrm{O}_{4} \mathrm{NPs}$ is due to $\mathrm{Ce}^{4+} /$ $\mathrm{Ce}^{3+}$ oxidation state and high mobility of surface oxygen. We have studied this activity by catalytic oxidation of catechol. The study explains the oxidation of catechol by $\mathrm{CeO}_{2}-\mathrm{Fe}_{3} \mathrm{O}_{4} \mathrm{NPs}$ and the analogous absorption spectra for quinone complex generated by $9 \mathrm{~nm}$ particle size of $\mathrm{CeO}_{2}-\mathrm{Fe}_{3} \mathrm{O}_{4} \mathrm{NPs}$. The color of particle dispersed catechol solution changed from transparent to brown. The intensity of the color is dependent on the concentration of catechol and $\mathrm{CeO}_{2}-\mathrm{Fe}_{3} \mathrm{O}_{4} \mathrm{NPs}$. These color changes are due to oxidation of catechol by $\mathrm{CeO}_{2}-\mathrm{Fe}_{3} \mathrm{O}_{4} \mathrm{NPs}$ and formation of quinone complex, the schematic of mechanism is shown in Fig. 6. Oxidation and formation of quinone complexes with inner transition metals and phenolic compound by FTIR, XPS, and UV-vis spectroscopy have been reported previously [7].

XPS analysis (Fig. 4) shows that significant change in optical properties is due to $\mathrm{Ce}^{3+}$ and $\mathrm{Ce}^{4+}$ in $\mathrm{CeO}_{2}-\mathrm{Fe}_{3} \mathrm{O}_{4}$ nanoparticle system. Therefore, catechol ligand forms quinone complex due to surface modification of 
<smiles>Oc1ccccc1O</smiles>

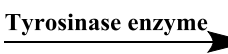

Catechol
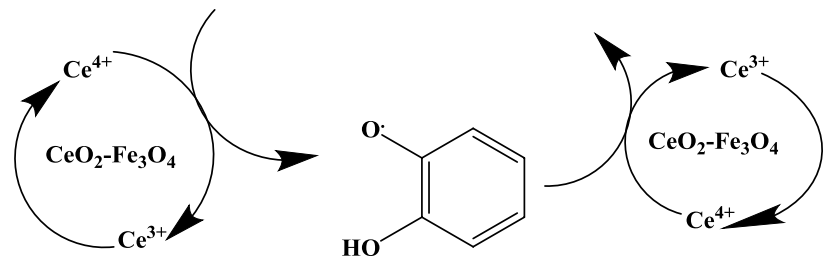

Fig. 6 Schematic mechanism of $\mathrm{CeO}_{2}-\mathrm{Fe}_{3} \mathrm{O}_{4} \mathrm{NPs}$ for catechol detection

$\mathrm{CeO}_{2}-\mathrm{Fe}_{3} \mathrm{O}_{4}$ NPs. Quinone complex has a metal-catecholate bond with both sigma ( $\sigma$ ) andn-donar bonding contribution [37]. Also, due to charge transfer, the colorless catechol gives colored quinone complex.

To confirm the oxidase-like activity of $\mathrm{CeO}_{2}-\mathrm{Fe}_{3} \mathrm{O}_{4} \mathrm{NPs}$ for catechol detection it was compared with tyrosinase enzyme. Tyrosinase enzyme changes optical properties of the reaction mixture and similar change in optical properties of the reaction mixture are shown by $\mathrm{CeO}_{2}-\mathrm{Fe}_{3} \mathrm{O}_{4} \mathrm{NPs}$. However, these nanoparticles can be used to replace conventional tyrosinase enzyme for catechol detection and exceptional method for polyphenol compounds detection.

\subsection{Effect of catechol concentration}

To study the effect of catechol concentration on tyrosinase enzyme and $\mathrm{CeO}_{2}-\mathrm{Fe}_{3} \mathrm{O}_{4} \mathrm{NPs}, 1-7 \mathrm{mM}$ catechol solution was prepared in $\mathrm{pH} 7.8$ phosphate buffer solution $(0.2 \mathrm{M})$. These catechol solutions were added to $5 \mathrm{mg}$ of $\mathrm{CeO}_{2}-\mathrm{Fe}_{3} \mathrm{O}_{4} \mathrm{NPs}$ and $2 \mathrm{~mL}$ of $2000 \mathrm{ppm}$ of tyrosinase (1 $\mathrm{KU} / \mathrm{mg}$ ) separately. Figure $7 \mathrm{a}, \mathrm{b}$ show absorbance in the visible region by tyrosinase enzyme and $\mathrm{CeO}_{2}-\mathrm{Fe}_{3} \mathrm{O}_{4} \mathrm{NPs}$ respectively. It can be inferred from the Fig. $7 a, b$ that the colorless catechol solution gives colored quinone complex. Figure $7 \mathrm{a}, \mathrm{b}$ demonstrates that with an increase in the catechol concentration, absorbance also increases and $5 \mathrm{mM}$ catechol solution gives maximum absorbance for quinone complex. Hence, further experiments were carried out by using a $5 \mathrm{mM}$ catechol solution. Figure $7 \mathrm{c}$ shows the calibration curve for catechol, where the absorbance of catechol increases linearly with the increasing concentration of catechol. The rapid color change and strong absorbance prove that $\mathrm{CeO}_{2}-\mathrm{Fe}_{3} \mathrm{O}_{4} \mathrm{NPs}$ can be used for oxidation and as a color indicator reagent similar as tyrosinase for catechol detection.
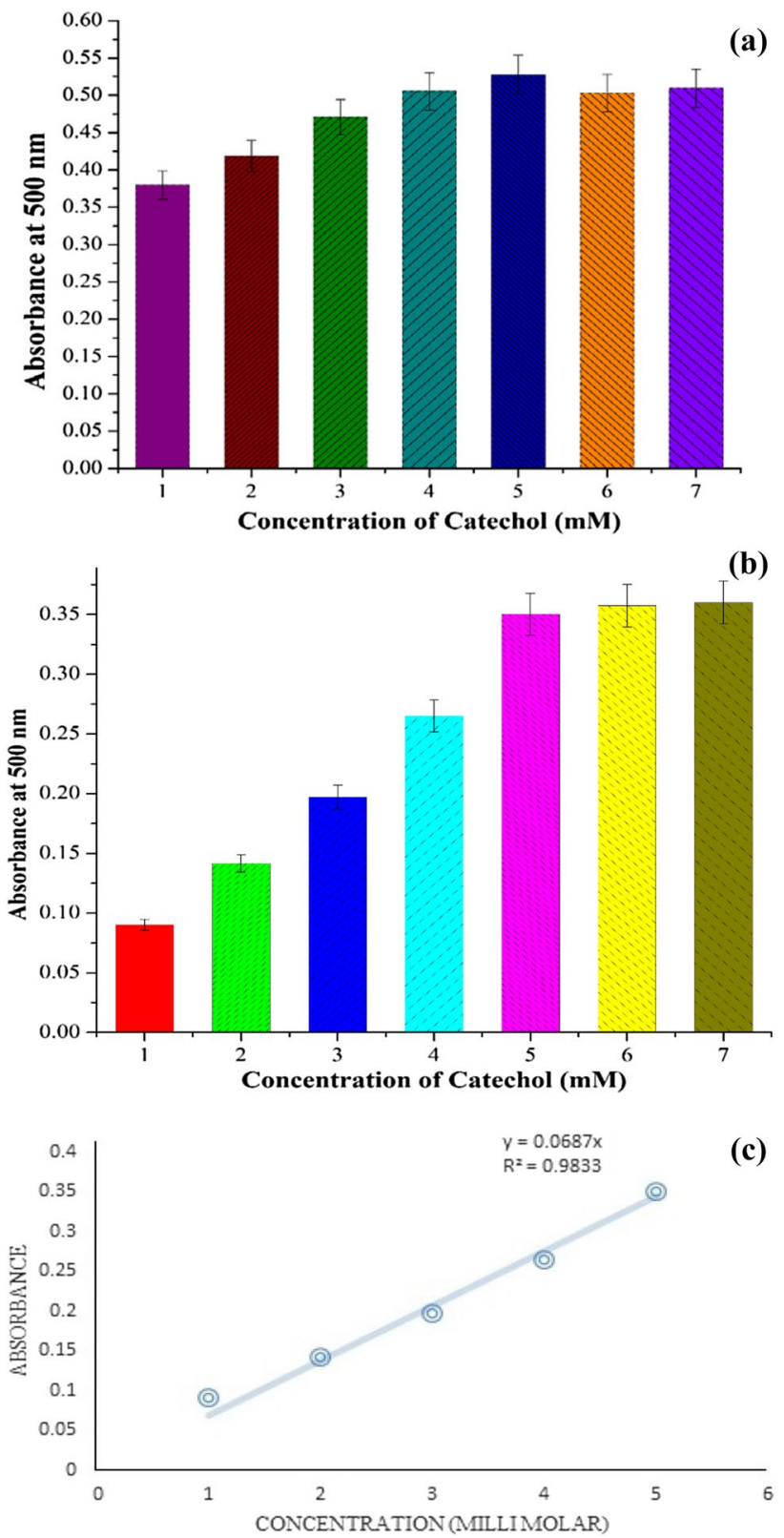

Fig. 7 a Effect of catechol concentration by using tyrosinase enzyme, $\mathbf{b}$ effect of catechol concentration by using $\mathrm{CeO}_{2}-\mathrm{Fe}_{3} \mathrm{O}_{4}$ NPs, c calibration curve for catechol

\subsection{Effect of ionic strength and buffer composition}

Enzyme mimic properties of nanoparticles are greatly dependent on the buffer anions of reaction medium $[10,37]$. Therefore, it is important to study the effect of ionic strength. Figure 8 a shows that in the absence of $\mathrm{CeO}_{2}-\mathrm{Fe}_{3} \mathrm{O}_{4} \mathrm{NPs}$ the solution containing catechol in phosphate buffer is colorless and has no absorption in 400-800 nm. However, in the presence of $\mathrm{CeO}_{2}-\mathrm{Fe}_{3} \mathrm{O}_{4} \mathrm{NPs}$, the solution becomes colored with maximum absorbance in a visible range (Fig. 8b). The absorbance originates from 


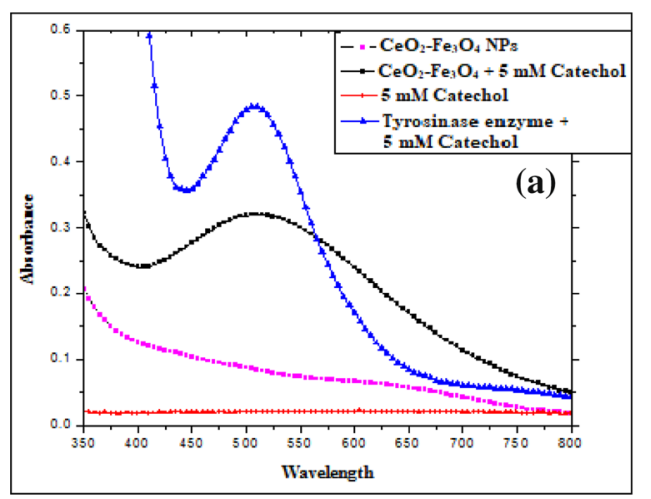

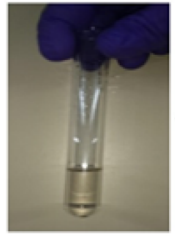

Catechol (b)
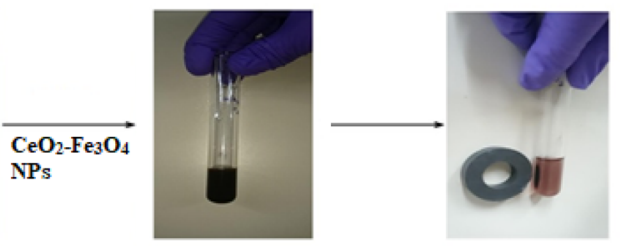

Catechol o-quinone
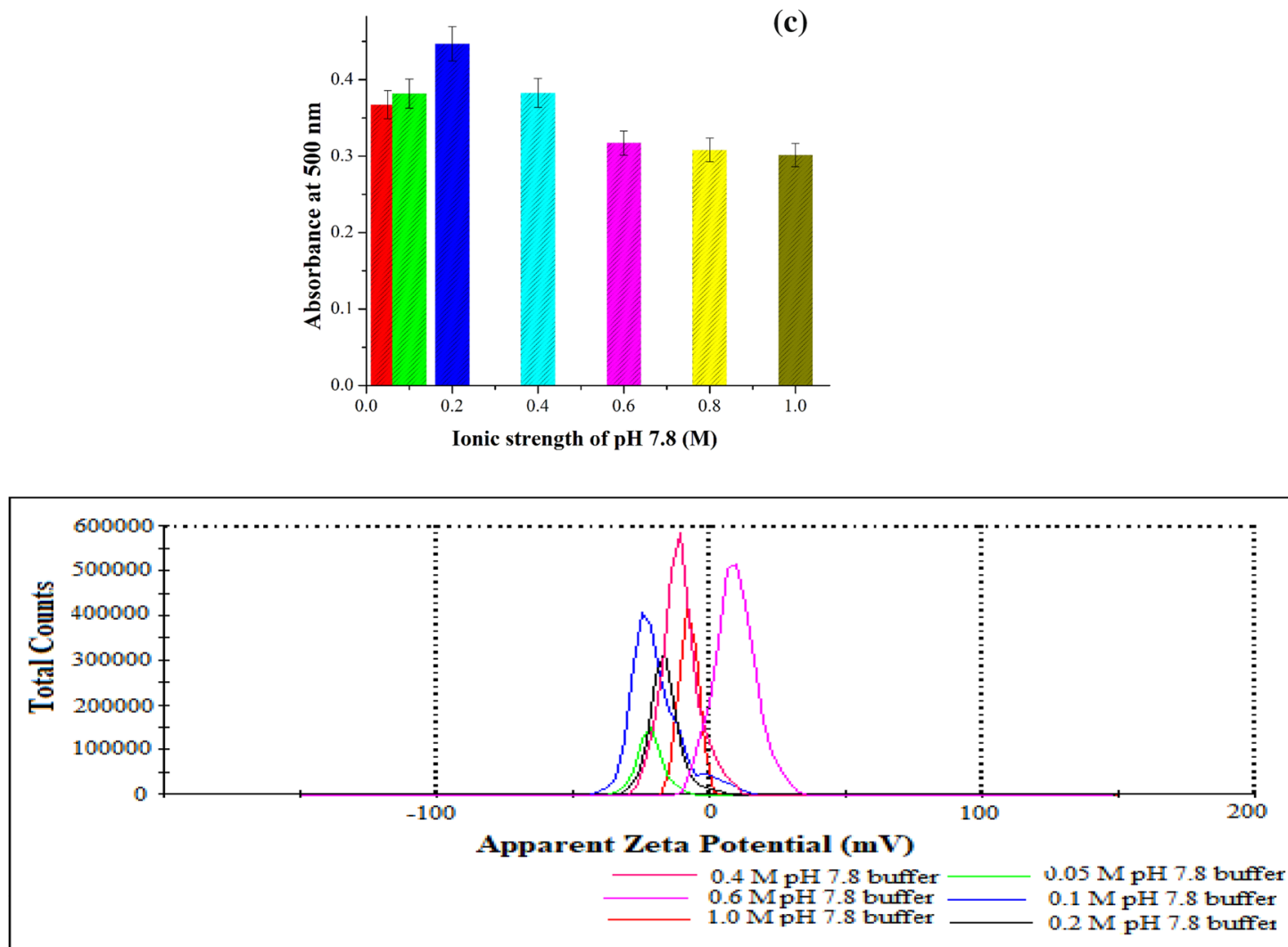

(d)

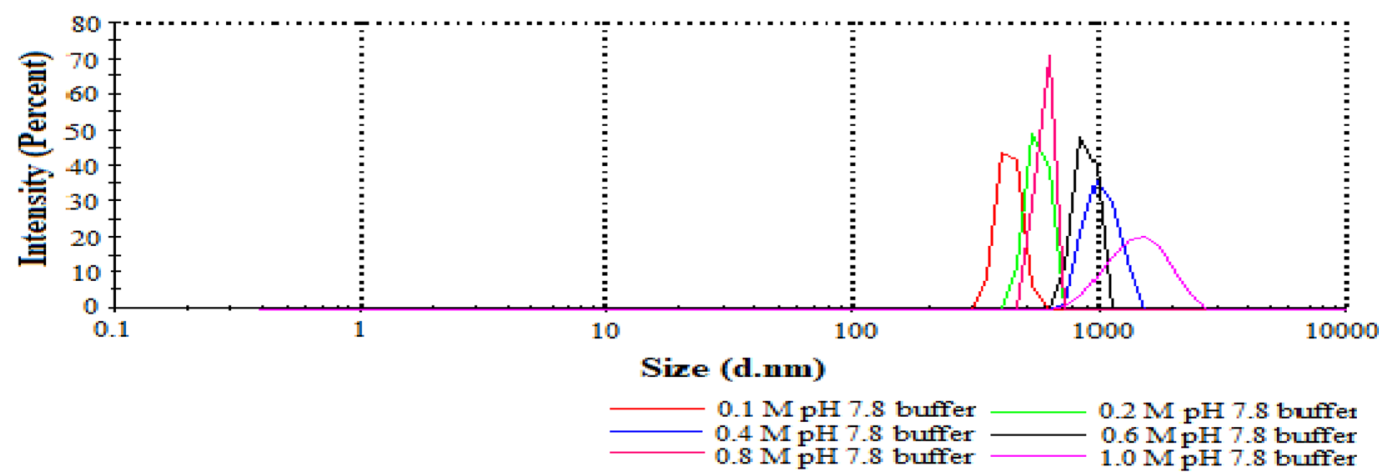

Fig. 8 a UV-vis spectra in Buffer for (i) catechol (5 mM), (ii) $\mathrm{CeO}_{2}-$ $\mathrm{Fe}_{3} \mathrm{O}_{4} \mathrm{NPs}(5 \mathrm{mg})$, (iii) catechol $(5 \mathrm{mM})$ with $5 \mathrm{mg} \mathrm{CeO}-\mathrm{Fe}_{3} \mathrm{O}_{4} \mathrm{NPs}$, b the color changed by $\mathrm{CeO}_{2}-\mathrm{Fe}_{3} \mathrm{O}_{4} \mathrm{NPs}$ dispersed in catechol solu- tion, $\mathbf{c}$ effect of buffer ionic strength on $\mathrm{CeO}_{2}-\mathrm{Fe}_{3} \mathrm{O}_{4} \mathrm{NPs}$ interaction with $5 \mathrm{mM}$ catechol, $\mathbf{d}$ effect of buffer ionic strength on particle size and zeta potential of $\mathrm{CeO}_{2}-\mathrm{Fe}_{3} \mathrm{O}_{4} \mathrm{NPs}$ 
Table 1 Study of ionic strength on catechol oxidase activity of $\mathrm{CeO}_{2}-\mathrm{Fe}_{3} \mathrm{O}_{4} \mathrm{NPs}$ by using dynamic light scattering (DLS) and zeta potential

\begin{tabular}{llll}
\hline Sr. no. & $\begin{array}{l}\text { Phosphate buffer } \\
\text { concentration }(\mathrm{M})\end{array}$ & $\begin{array}{l}\text { DLS particle size } \\
\text { distribution }(\mathrm{nm})\end{array}$ & $\begin{array}{l}\text { Zeta } \\
\text { potential } \\
(\mathrm{mV})\end{array}$ \\
\hline 1 & 0.05 & 406 & -20.97 \\
2 & 0.1 & 426 & -20.83 \\
3 & 0.2 & 555.4 & -16.4 \\
4 & 0.4 & 590.6 & -10.85 \\
5 & 0.6 & 864.1 & -10.30 \\
6 & 1 & 1442 & -7.70 \\
\hline
\end{tabular}

oxidation of catechol to colored quinone complex, similar to the phenomenon observed for tyrosinase enzyme in Fig. 8a [1]. To study ionic strength behavior, catechol oxidase like activity of nanoparticles in phosphate buffer solution (PBS) from 0.05 to $1 \mathrm{M}$ at pH 7.8 was prepared. However, Fig. 8c shows $0.2 \mathrm{M}$ phosphate buffer gives maximum absorbance. Higher concentration of PBS induced significant particle aggregation and was not used for detection. The occurrence of phosphate anion has an undesirable change in oxidase activity of nanoparticles. The decrease in absorbance was observed with an increase in ionic strength from 0.2 to $1 \mathrm{M}$ buffer solution. The loss of reactivity in these buffers is due to the formation of metal phosphate on the surface of particles that results in partial inactivation of the surface. Therefore, they block the interconversion between $\mathrm{Ce}^{4+} / \mathrm{Ce}^{3+}$ and inhibit reaction with catechol.

To prove this assumption, dynamic light scattering (DLS) and zeta potential experiments were used to study the formation of metal phosphate and aggregation of particles. Figure $8 \mathrm{~d}$ and Table 1 explains the values observed by increasing the concentration of PBS (0.05-1 M), which shows particle size increase from $406 \pm 50 \mathrm{~nm}$ and change of zeta potential from $-20.97 \pm 2$ to $-7.70 \pm 2 \mathrm{mV}$.

Change in surface properties of nanoparticles is observed by the change in zeta potential values, which confirms the formation of metal phosphate on the surface $[1,10]$. DLS and zeta potential experimental results are given in Table 1. This shows that the change in the reaction is due to physicochemical properties of NPs as well as the buffer environment.

\subsection{Effect of nanoparticle concentration}

Reactive surface of the $\mathrm{CeO}_{2}-\mathrm{Fe}_{3} \mathrm{O}_{4} \mathrm{NPs}$ are responsible for oxidase like activity and more the reactive surface of NPs more will be the activity. The different concentrations of $\mathrm{CeO}_{2}-\mathrm{Fe}_{3} \mathrm{O}_{4} \mathrm{NPs}$ ranging from 1 to $9 \mathrm{mg}$ were added

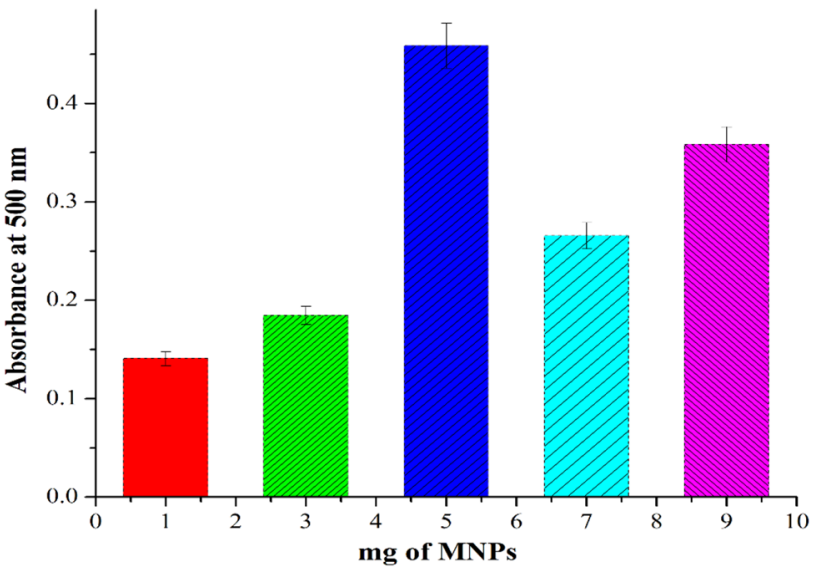

Fig. 9 Effect of different concentrations of $\mathrm{CeO}_{2}-\mathrm{Fe}_{3} \mathrm{O}_{4} \mathrm{NPs}$ in pH-7.8 phosphate buffer $(0.2 \mathrm{M})$ in presence of $5 \mathrm{mM}$ catechol

to a fixed concentration of catechol and absorbance was measured by UV-vis spectrophotometer.

Figure 9 shows $\mathrm{CeO}_{2}-\mathrm{Fe}_{3} \mathrm{O}_{4} \mathrm{NPs}$ in $\mathrm{pH}-7.8$ phosphate buffer $(0.2 \mathrm{M})$ in presence of $5 \mathrm{mM}$ catechol. It can be concluded that absorbance change in different concentrations of $\mathrm{CeO}_{2}-\mathrm{Fe}_{3} \mathrm{O}_{4} \mathrm{NPs}$ was due to different chemical structures and redox potentials. It can be seen that $5 \mathrm{mg}$ $\mathrm{CeO}_{2}-\mathrm{Fe}_{3} \mathrm{O}_{4} \mathrm{NPs}$ shows maximum absorbance and this was selected as an optimum concentration for quinone complex formation $[8,9]$.

\subsection{Effect of time}

The inset of Fig. 10 shows the time-dependent catalytic activity of $\mathrm{CeO}_{2}-\mathrm{Fe}_{3} \mathrm{O}_{4} \mathrm{NPs}$ under standard conditions. In order to study the effect of time, $5 \mathrm{mg}$ of $\mathrm{CeO}_{2}-\mathrm{Fe}_{3} \mathrm{O}_{4} \mathrm{NPs}$ was added in $5 \mathrm{mM}$ catechol solution having phosphate buffer $(0.2 \mathrm{M})$ of $\mathrm{pH}$ 7.8. The colorless catechol solution gives colored quinone complex, which shows absorbance

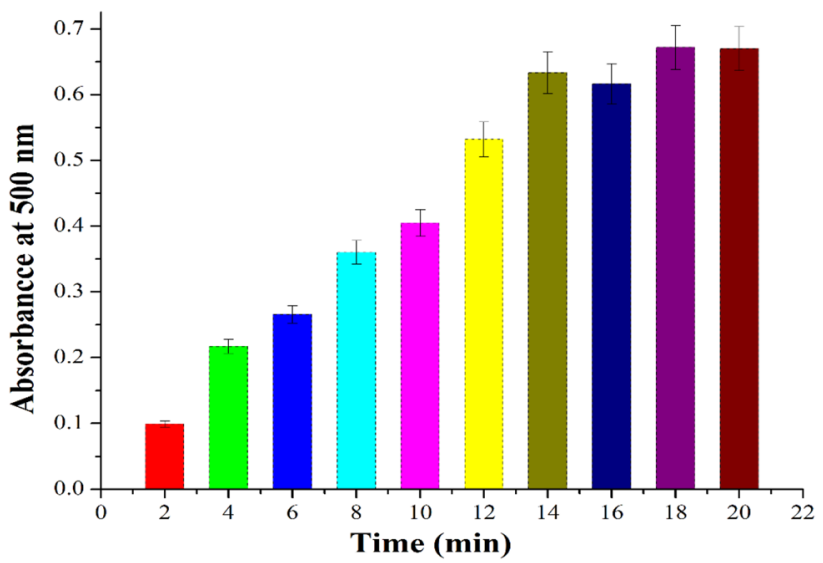

Fig. 10 Effect of time on catechol detection 
in a visible region. Optical properties of the samples were measured at 2-20 $\mathrm{min}$. As the reaction proceeds, the colorless solution becomes colored quinone complex, and maximum absorbance was observed at $14 \mathrm{~min}$. Further increase in reaction time shows an insignificant change in the quinone complex formation. The difference in absorbance intensity is attributed by different catalytic activities of $\mathrm{CeO}_{2}-\mathrm{Fe}_{3} \mathrm{O}_{4} \mathrm{NPs}$ with time. Also, $\mathrm{CeO}_{2}-\mathrm{Fe}_{3} \mathrm{O}_{4} \mathrm{NPs}$ with different physical properties have different chemical reactivities [8]. Therefore, $14 \mathrm{~min}$ was selected as the optimum time for $\mathrm{CeO}_{2}-\mathrm{Fe}_{3} \mathrm{O}_{4} \mathrm{NPs}$ as enzyme mimic to detect catechol.

\subsection{Reusability}

A recyclable catalyst is key in the case of economic feasibility. $\mathrm{CeO}_{2}-\mathrm{Fe}_{3} \mathrm{O}_{4} \mathrm{NPs}$ was successively reused until the fourth cycle (Fig. 11). After each cycle, $\mathrm{CeO}_{2}-\mathrm{Fe}_{3} \mathrm{O}_{4} \mathrm{NPs}$ was washed with DI water three times and reused for the fresh cycle. After four consecutive cycles of reuse, it retains $82 \%$ residual activity and shows excellent reusability and durability of $\mathrm{CeO}_{2}-\mathrm{Fe}_{3} \mathrm{O}_{4} \mathrm{NPs}$. Its activity might be reduced due to substrate poisoning [1].

\subsection{Kinetics study}

The oxidase like activity was further carried out by using $5 \mathrm{mg} \mathrm{CeO}{ }_{2}-\mathrm{Fe}_{3} \mathrm{O}_{4} \mathrm{NPs}$ in $5 \mathrm{mM}$ catechol, prepared in phosphate buffer ( $\mathrm{pH}-7.8,0.2 \mathrm{M})$ up to $1 \mathrm{~h}$. By using the equation below catechol concentration ( $\mathrm{Ca}$ ) was determined. Figure 12 illustrates that the concentration of the reactant (Ca) decreased linearly as time passed. This indicates that the reaction followed first-order kinetics with respect to the concentration of catechol.

$\mathrm{Ca}=\mathrm{CaO}+\mathrm{CbO}-\mathrm{Cb}$

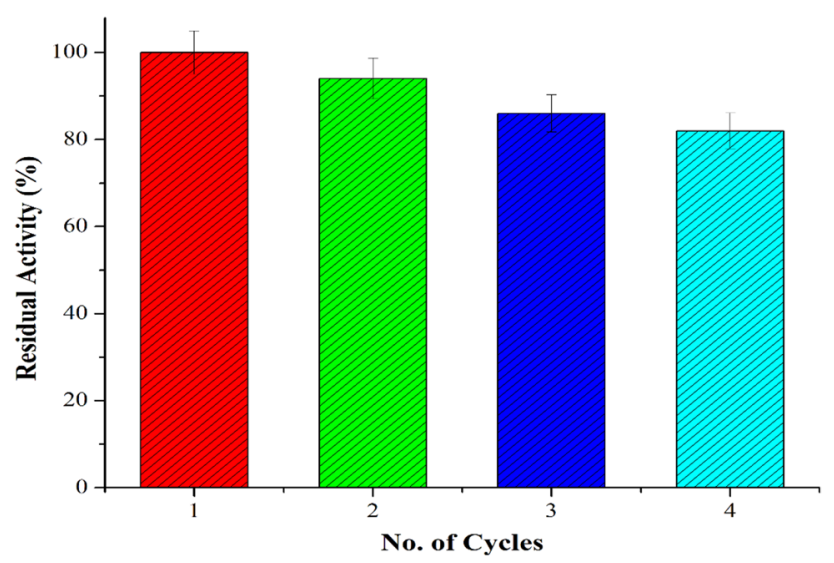

Fig. 11 Reusability of $\mathrm{CeO}_{2}-\mathrm{Fe}_{3} \mathrm{O}_{4} \mathrm{NPs}$

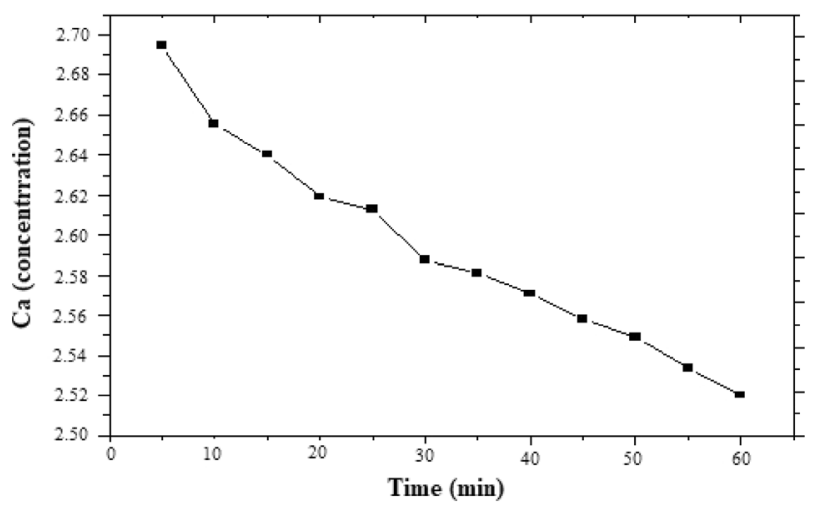

Fig. 12 Kinetics study of reaction

where $\mathrm{Ca}$, catechol concentration at a time; $\mathrm{Cb}$, quinone complex concentration at a time; $\mathrm{CaO}$, initial concentration of catechol; $\mathrm{CbO}$, initial concentration of quinone complex.

\subsection{Interference study}

It is essential to prevent the interference of ascorbic acid for the selective detection of catechol [38]. The study was carried out by adding ascorbic acid in $\mathrm{pH} 7.8$ phosphate buffer containing $\mathrm{CeO}_{2}-\mathrm{Fe}_{3} \mathrm{O}_{4} \mathrm{NPs}$ and catechol, the absorbance of colored solution was measured in the visible region and compared with the colorless ascorbic acid solution. The ascorbic acid solution does not change its color by adding $\mathrm{CeO}_{2}-\mathrm{Fe}_{3} \mathrm{O}_{4}$ NPs. Therefore from Fig. 13, it is concluded that there is no interference of ascorbic acid for catechol detection.

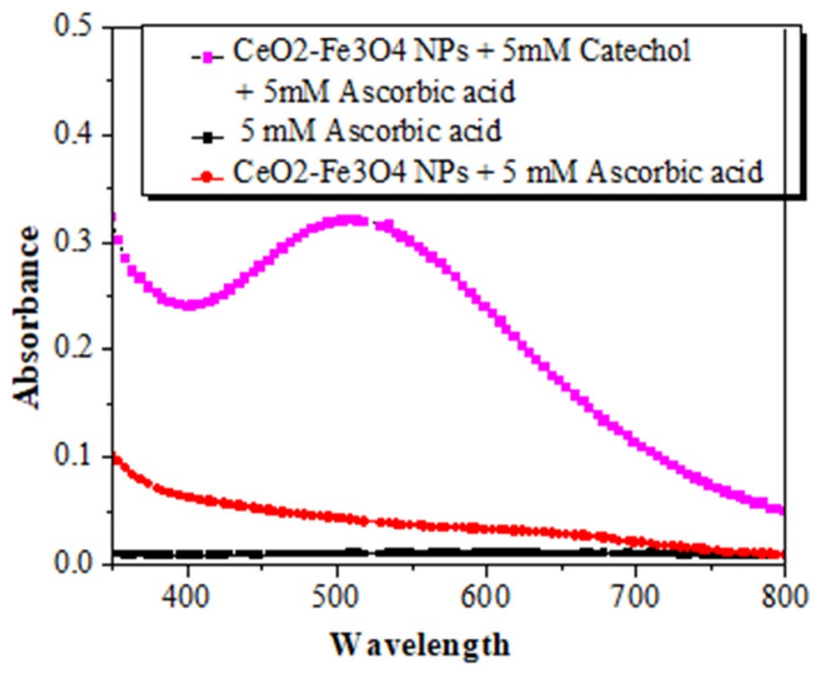

Fig. 13 Interference study of ascorbic acid for catechol detection by $\mathrm{CeO}_{2}-\mathrm{Fe}_{3} \mathrm{O}_{4} \mathrm{NPs}$ 


\section{Conclusion}

The current study explains the various effects of $\mathrm{CeO}_{2}-\mathrm{Fe}_{3} \mathrm{O}_{4}$ nanomaterials as enzyme mimic. The $\mathrm{CeO}_{2}-\mathrm{Fe}_{3} \mathrm{O}_{4} \mathrm{NPs}$ have been used for the first time as enzyme mimic properties for catechol detection. The XPS study of $\mathrm{CeO}_{2}-\mathrm{Fe}_{3} \mathrm{O}_{4} \mathrm{NPs}$ reveals that the $\mathrm{Ce}$, Fe and O Elements are present and the combination of $\mathrm{Fe}^{2+}, \mathrm{Fe}^{3+}$ is confirmed due to the satellite signal. The colorless catechol to colored quinone complex follows first order kinetics. This is mostly due to the surface modification and charge transfer properties of nanoparticles. The quinone complex has the metal-catecholate bond with both sigma ( $\sigma)$ and pi (ח ) donar bonding contribution. On the other hand, DLS and zeta potential study shows that with an increase in ionic strength of PBS, oxidase like activity of $\mathrm{CeO}_{2}-\mathrm{Fe}_{3} \mathrm{O}_{4} \mathrm{NPs}$ decreases. This was due to the variation in surface properties of nanoparticles and was indicative of the formation of metal phosphate. Also, reusability of $\mathrm{CeO}_{2}-\mathrm{Fe}_{3} \mathrm{O}_{4} \mathrm{NPs}$ was studied till the fourth cycle in batch mode. The future study requires to deposit other metals on the $\mathrm{Fe}_{3} \mathrm{O}_{4}$ surface to know more about surface charges and oxidase mimic activity of metal nanoparticles. Such studies on enzyme mimicking nanoparticles help as guiding principle for the development of other nanoparticles based enzyme mimetics.

Acknowledgements The authors would like to acknowledge the University Grants Commission (UGC) of India for financial assistance in the research work.

\section{Compliance with ethical standards}

Conflict of interest The authors declare that they have no conflict of interest.

\section{References}

1. Hayat A, Cunningham J, Bulbul G, Andreescu S (2015) Evaluation of the oxidase like activity of nanoceria and its application in colorimetric assays. Anal Chim Acta 885:140-147. https://doi. org/10.1016/j.aca.2015.04.052

2. Wei $\mathrm{H}$, Wang $\mathrm{E}$ (2008) $\mathrm{Fe}_{3} \mathrm{O}_{4}$ magnetic nanoparticles as peroxidase mimetics and their applications in $\mathrm{H}_{2} \mathrm{O}_{2}$ and glucose detection. Anal Chem 80:2250-2254. https://doi.org/10.1021/ac702 $203 f$

3. Mu J, Wang $Y$, Zhao $M$, Zhang $L$ (2012) Intrinsic peroxidase-like activity and catalase-like activity of $\mathrm{Co}_{3} \mathrm{O}_{4}$ nanoparticles. Chem Commun 48:2540-2542. https://doi.org/10.1039/c2cc17013b

4. Wei H, Wang E (2013) Nanomaterials with enzyme-like characteristics (nanozymes): next-generation artificial enzymes. Chem Soc Rev 42:6060-6093. https://doi.org/10.1039/c3cs35486e

5. Chaudhari KN, Chaudhari NK, Yu J-S (2012) Peroxidase mimic activity of hematite iron oxides (alpha- $\mathrm{Fe}(2) \mathrm{O}(3)$ ) with different nanostructres. Catal Sci Technol 2:119-124. https://doi. org/10.1039/c1cy00124h
6. Fiammengo R, Jäschke A (2005) Nucleic acid enzymes. Curr Opin Biotechnol 16:614-621. https://doi.org/10.1016/j.copbi 0.2005 .10 .006

7. Hayat A, Andreescu D, Bulbul G, Andreescu S (2014) Redox reactivity of cerium oxide nanoparticles against dopamine. J Colloid Interface Sci 418:240-245. https://doi.org/10.1016/j. jcis.2013.12.007

8. Peng X, Manna L, Yang W et al (2000) Shape control of CdSe nanocrystals. Nature 404:59-61. https://doi.org/10.1038/35003 535

9. Fang B, Kim M-S, Kim JH et al (2011) High Pt loading on functionalized multiwall carbon nanotubes as a highly efficient cathode electrocatalyst for proton exchange membrane fuel cells. J Mater Chem 21:8066. https://doi.org/10.1039/c1jm10847f

10. Xue $Y$, Zhai $Y$, Zhou K et al (2012) The vital role of buffer anions in the antioxidant activity of $\mathrm{CeO}_{2}$ nanoparticles. Chem A Eur J 18:11115-11122. https://doi.org/10.1002/chem.201200983

11. Singh S, Dosani T, Karakoti AS et al (2011) A phosphate-dependent shift in redox state of cerium oxide nanoparticles and its effects on catalytic properties. Biomaterials 32:6745-6753. https ://doi.org/10.1016/j.biomaterials.2011.05.073

12. Han MJ, Yoo KS, Chang JY, Ha TK (2000) 5-( $\beta$-Cyclodextrinylamino)5-deoxy-a-D-riboses as models for nuclease, ligase, phosphatase, and phosphorylase. Angew Chem Int Ed 39:347-349. https://doi. org/10.1002/(SICI)1521-3773(20000117)39:2\%3c347:AID-ANIE3 47\%3e3.0.CO;2-Q

13. Muche MS, Gobel MW (1996) Bis (guanidinium) alcohols as models of staphylococcal nuclease: substrate binding through ion pair complexes and fast phosphoryl transfer reactions. Angew Chem Int Ed Engl 11:26-29. https://doi.org/10.1002/anie.199621261

14. Wang Z, Yang X, Yang J et al (2015) Peroxidase-like activity of mesoporous silica encapsulated Pt nanoparticle and its application in colorimetric immunoassay. Anal Chim Acta 862:53-63. https://doi.org/10.1016/j.aca.2014.12.046

15. Wang C, Chen W, Chang H (2012) Enzyme mimics of Au/Ag nanoparticles for fluorescent detection of acetylcholine. Anal Chem 84:9706-9712. https://doi.org/10.1021/ac300867s

16. Tang Z, Wu H, Zhang $\mathrm{Y}$ et al (2011) Enzyme-mimic activity of ferric nano-core residing in ferritin and its biosensing applications. Anal Chem 83:8611-8616. https://doi.org/10.1021/ac202049q

17. Lin Y, Ren J, Qu X (2014) Nano-gold as artificial enzymes: hidden talents. Adv Mater 26:4200-4217. https://doi.org/10.1002/ adma.201400238

18. Wang Z, Chen M, Shu J, Li Y (2016) One-step solvothermal synthesis of Fe304@Cu@Cu2O nanocomposite as magnetically recyclable mimetic peroxidase. J Alloys Compd 682:432-440. https://doi.org/10.1016/j.jallcom.2016.04.269

19. Li S, Liu X, Chai H, Huang Y (2018) Recent advances in the construction and analytical applications of metal-organic frameworks-based nanozymes. Trends Anal Chem 105:391-403. https ://doi.org/10.1016/j.trac.2018.06.001

20. Zhao J, DongW Zhang X, Chai H, Huang Y (2018) FeNPs@Co3O4 hollow nanocages hybrids as effective peroxidase mimics for glucose biosensing. Sens Actuators B 263:575-584. https://doi. org/10.1016/j.snb.2018.02.151

21. Li S, Wanga L, Zhanga X, Chai H, Huanga Y (2018) A Co, N codoped hierarchically porous carbon hybrid as a highly efficient oxidase mimetic for glutathione detection. Sens Actuators B 264:312-319. https://doi.org/10.1016/j.snb.2018.03.015

22. Zhang W, Ma D, Du J (2014) Prussian blue nanoparticles as peroxidase mimetics for sensitive colorimetric detection of hydrogen peroxide and glucose. Talanta 120:362-367. https://doi. org/10.1016/j.talanta.2013.12.028

23. Asati MA, Santra DS, Kaittanis MC et al (2010) Oxidase activity of polymer-coated cerium oxide nanoparticles. Angew Chem 
48:2308-2312. https://doi.org/10.1002/anie.200805279.Oxida se

24. Chen Z, Yin JJ, Zhou YT et al (2012) Dual enzyme-like activities of iron oxide nanoparticles and their implication for diminishing cytotoxicity. ACS Nano 6:4001-4012. https://doi.org/10.1021/ nn300291r

25. Niphadkar SS, Vetal MD, Rathod VK (2014) Purification and characterization of polyphenol oxidase from waste potato peel by aqueous two phase extraction. Prep Biochem Biotechnol 6068:37-41. https://doi.org/10.1080/10826068.2014.940970

26. Sojitra UV, Nadar SS, Rathod VK (2016) A magnetic tri-enzyme nanobiocatalyst for fruit juice clarification. Food Chem 213:296305. https://doi.org/10.1016/j.foodchem.2016.06.074

27. Nadar SS, Rathod VK (2016) Magnetic macromolecular cross linked enzyme aggregates (CLEAs) of glucoamylase. Enzyme Microb Technol 83:78-87. https://doi.org/10.1016/j.enzmi ctec.2015.10.009

28. Sojitra UV, Nadar SS, Rathod VK (2016) Immobilization of pectinase onto chitosan magnetic nanoparticles by macromolecular cross-linker. Carbohydr Polym 157:677-685. https://doi. org/10.1016/j.carbpol.2016.10.018

29. Gawande MB, Bonifácio VDB, Varma RS et al (2013) Magnetically recyclable magnetite-ceria (Nanocat-Fe-Ce) nanocatalyst-applications in multicomponent reactions under benign conditions. Green Chem 15:1226. https://doi.org/10.1039/c3gc4 0375k

30. Wang N, Zhu L, Wang D et al (2010) Sono-assisted preparation of highly-efficient peroxidase-like $\mathrm{Fe}_{3} \mathrm{O}_{4}$ magnetic nanoparticles for catalytic removal of organic pollutants with $\mathrm{H}_{2} \mathrm{O}_{2}$. Ultrason Sonochem 17:526-533. https://doi.org/10.1016/j.ultso nch.2009.11.001

31. Gupta H, Paul P, Kumar N et al (2014) One pot synthesis of waterdispersible dehydroascorbic acid coated $\mathrm{Fe}_{3} \mathrm{O}_{4}$ nanoparticles under atmospheric air: blood cell compatibility and enhanced magnetic resonance imaging. J Colloid Interface Sci 430:221228. https://doi.org/10.1016/j.jcis.2014.05.043
32. Jain R, Dubey A et al (2015) Gas-solid interaction of $\mathrm{H} 2-\mathrm{Ce} 0.95 \mathrm{Zr} 0.05 \mathrm{O} 2$ : new insights on surface participation in heterogeneous catalysis. Catal Sci Technol. https://doi. org/10.1039/C5CY01428J

33. Beche E, Charvin P, Perarnau D, Abanades S, Flament G (2008) Ce 3d XPS investigation of cerium oxides and mixed cerium oxide (CexTiyOz). Surf Interface Anal 40:264-267. https://doi. org/10.1002/sia.2686

34. Uhlig I, Szargam R, Nesbitt H, Laajalehto K (2001) Surface states and reactivity of pyrite and marcasite. Appl Surf Sci 179:222229. https://doi.org/10.1016/S0169-4332(01)00283-5

35. Ai Z, Zhang L, Lee S, Ho W (2009) Interfacial hydrothermal synthesis of Cu@Cu2O core-shell microspheres with enhanced visible-light-driven photocatalytic activity. J Phys Chem C 113:20896-20902. https://doi.org/10.1021/jp9083647

36. Movahed SK, Dabiri M, Bazgir A (2014) A one-step method for preparation of $\mathrm{Cu} @ \mathrm{Cu} 2 \mathrm{O}$ nanoparticles on reduced graphene oxide and their catalytic activities in $\mathrm{N}$-arylation of $\mathrm{N}$-heterocycles. Appl Catal A Gen 481:79-88. https://doi.org/10.1016/j. apcata.2014.04.023

37. Turcheniuk K, Tarasevych AV, Kukhar VP et al (2013) Recent advances in surface chemistry strategies for the fabrication of functional iron oxide based magnetic nanoparticles. Nanoscale 5:10729-10752. https://doi.org/10.1039/c3nr04131j

38. Rashid M, Auger V, Ali Z (2014) Simultaneous electrochemical detection of dopamine, catechol and ascorbic acid at a poly(acriflavine) modified electrode. In: XIII Mediterranean conference on medical and biological engineering and computing 2013. Springer, Basel. https://doi.org/10.1007/978-3-319-00846 $-2 \_221$

Publisher's Note Springer Nature remains neutral with regard to jurisdictional claims in published maps and institutional affiliations. 